\title{
PROMOTING SOCIALLY RESPONSIBLE BUSINESS AT ENTERPRISE LEVEL: THEORETICAL APPROACH
}

\author{
Asta VALACKIENE் ${ }^{1}$, Diana MICEVIČIENÉ2 \\ Faculty of Management and Administration, Technology Panevėžys Institute \\ of Kaunas University of Technology, Nemuno str. 33, Panevėžys, Lithuania \\ E-mails: 1asta.valackiene@ktu.lt (corresponding author); 2 diana.miceviciene@ktu.lt
}

Received 27 April 2012; accepted 29 October 2012

\begin{abstract}
The paper highlights theoretical construct of the new methodological approach presenting the interaction between the corporate social responsibility and the performance of the sustainable enterprise, through the introduction of the methodological framework of the diagnosis of corporate social responsibility motivations at the level of a firm seeking to sustain. Acting without knowing all (or at least enough) the answers may mean that we purposely shift our focus to those areas where possible solutions do not emerge. However, entrepreneurship as a phenomenon entailing risk and high levels in daily activities is an engine by profit-seeking motives. It shows the complexity of the scientific research object that brings meaningful input into the analysis of the promotion of socially responsible business. This paper aims at discussing and presenting critical reviews of enterprise's commitment to corporate social responsibility with emphasis on methodological positions in its promotion. This implicates a shift from the pure stakeholder perspective of maximizing profits thought introduction of enterprise - level interventions in promoting socially responsible business.
\end{abstract}

Keywords: corporate social responsibility, sustainable enterprise, motivations, commitment, principles, stakeholders.

JEL Classification: M14, M21, P21.

\section{Introduction}

Recently liberalization and expansion of trade, growing interdependence and integration markets have not come about without causing significant changes both structural and cyclical into the operation of organizations and operations of states (Bourdages 1997). This form of development is also featured not only by growing mutual economic obligations but also growing accountability to the wide public. This transformational development or so called post modern vision of progress resulted in growing recognition of the sustainable development issues. This means that sustainable development provides a vision that ellipses modernity's concept of progress by redefining the intellectual and ethic 
challenges (Parrish 2007). Despite the fact that the construct is fundamentally infused with multiple and complex interdependences modern science it closely relates to the birth of social responsibility initiatives the have become a synonym for "corporate social responsibility" (CSR). Furthermore, the authors argue, CSR is about creating benefits through demonstrating a concern about key stakeholder both: internal and external in building so called "reservoir of social goodwill". Practice still demonstrates uniformity in how a corporate treat and report its CSR activities. This article goes into the discussion to what extent real progress has been made towards sustainable development adoption in enterprise level. In academic debate and business environments hundreds of concepts were proposed referring to a more humane, more ethical and transparent way of doing business (Van Marrewijk 2002) and it practice shows that "social responsibility moves CSR from being a minimal commitment or some social "add-on" to becoming a strategic necessity" (Werther, Chandler 2005: 317). However, the most complicated aspect of becoming socially responsible at the level of enterprise is that "maximizing profits and corporate value towards a broader concept that encompasses multiple stakeholder concerns and values and, thus, involves various conflicting goals and objectives" (Hediger 2010: 518). As Werther and Chandler (2005) notice, one of the most recently mentioned paradigm - CSR benefit if only in the case if desired social change is beneficial to the company itself. Branco and Rodriques (2006: 111) emphasize the direct benefit on the company's reputation. Authors state, that "investments in socially responsible activities may have internal benefits by helping a firm to develop new resources and capabilities which are related namely to know-how and corporate culture".

Inclusion of these two conflicting aspects into enterprise strategy is a great challenge requiring deeper investigation and formulation of valuable recommendations. Therefore, these insights give way to the novelty space. So, we construct the novelty of our research: the article proposes a practical instrument for diagnosing the strategic value of CSR attempting to map enterprise propensity towards certain areas of CSR disclosure. Regarding to the problematic questions rose above; we seek to propose an analytical framework for linking the concepts of CSR and enterprise sustainability.

In order to address this flaw the aim of the article is formulate as follows: to present methodological insights among CSR and performance of sustainable enterprise through introducing an instrument for diagnosis of CSR motivations at the level of a firm. In so doing, the article attempts to map enterprise's propensity towards certain areas of CSR disclosure seeking to make the emphasis for practitioners on each of the CSR domains. The goal pursued reveals the scientific problem of the article: how to promote conceptual goals of social responsibility at the level of enterprise

The methods of the research: comparative structural analysis and synthesis, logical analysis of academic literature, practical construction method of theoretical perspective. 


\section{Paradigm of socially responsible business}

Werther, Chandler (2005) found, that most contemporary writers encourage including societal externalities (that are reflected in neither price, nor purchase) into management strategy of any enterprises so that the issues of sustainable development would be achieved. More recent researchers recognize also that the term "sustainable development" as a characteristics of societal progress has been variously conceived in terms of "vision expression", "value change", "moral development", "social reorganization", "transformational process" towards a desired future or better world (Gladwin et al. 1995). However, "the core idea of the phenomenon was defined most influentially by The World Commission on Environment and Development (i.e., The Brundtland Commission): development which meets the needs of the present without compromising the ability of future generations to meet their own needs" (1987: 8). In its broadest sense, this normative abstraction has been widely accepted and endorsed by thousands of governmental, corporate, and other organizations worldwide (Gladwin et al. 1995: 876). The United Nations defined a set of Millennium Development Goals (MDGs), based on a resolution adopted by the General Assembly in September 2000 (The United Nations General Assembly 2000). It included such variables as human rights, health, education and environmental issues. Unfortunately, most authors believe, that the current level of uncertainty about the future in the sense of political, economic and ecological development does not facilitate sustainable decision making by public institutions, businesses or private individuals. However, "any advances in ecological sustainability require an inherent trade-off in economic profitability is slowly giving way to a very different perspective: sustainability, namely the balancing of economic health, social equity and environmental resilience, serves as the integrative concept which offers a long term perspective and provides opportunities for win-win solutions" (Cohen, Winn 2007: 34). Valackiene et al. (2012) in their study stress, that sustainable development seeks to place social and environmental objectives on equal footing with economic objectives - the so-called triple bottom line (TBL) consisting of three "3 Ps": profit, people and planet. Taking this into consideration it might be suggested that "sustainable development as a process of achieving human development in an inclusive, connected, equitable, prudent, and secure manner" (Markley, Davis 2007: 764). In other words it is the development in maintenance of balance between the human need to improve lifestyles that meansfeeling of well-being through making business preserving natural resources. So far most large firms now have explicit public sustainability policy statements and claim to apply a "triple bottom line" that considers a firm's financial, environmental, and social performance (Hall et al. 2010: 441). Much of the research on this topic is based on the assumption that entrepreneurship involves economic activity driven by self-interested profit-seeking motives). "In many cases, the term "corporate sustainability" has become a synonym for "corporate social responsibility" pursuing the goals of sustainable development" (Parrish 2009: 510). However practice demonstrates uniformity in how they treat and report their CSR activities in the context of sustainable development. 


\section{Reflections on socially responsible business content}

Basing on research results, Valackienè et al. (2012) basing on S. Torjman (2000) conclude that despite the fact that the desired objective of human wellbeing in the context of sustainable development is clear, it is still not very easy to determine which elements to include into the social dimension. The authors of the article stress, that the most problematic aspect here is its connections to the economic dimension: quality of work and level of income, are more obvious. The reason for stressing the social dimension of sustainable development lies in one of the objectives of the article - highlight the principles of socially responsible business. An understanding of the historical role that the "social" played in the development of a corporation in its modern activities, explains why the concept of sustainable development urges the society to look beyond the narrow financial interests in order to promote the broader interests of society. But just how those broader interests to be dedicated: by whom and for whom? As far as sustainable development refers to some kind of ideology, it must be noted that it provides a valuebased lens through which people understand the external events, Spector (2008) notes. Using this ideology as an instrument, businessmen proclaim their responsibility and to wide public. In is essential that businesses assume responsibility in order to ensure the continuance of economic order and healthy evolution. The conclusion was drawn basing on Font and Harris (2004), Banerjee (2008), Spector (2008) research. Further understanding and the role of CSR in everyday business activities is discussed in the following chapters of the article.

\section{Initiatives and prerequisites of socially responsible business: strategic value for enterprises}

Recent evidences showed that "attention for corporate social responsibility has increased significantly and the essential issues on the topic became a popular discussion in the academic research. In recent years scholars and mangers have developed greater attention to the strategic implications of CSR" (Valackienè, Micevičiene 2012: 205). According to Harwood et al. (2011: 283), CSR initiatives became even more questionable at present: "there have been many articles and media questioning the resilience of CSR programmes in the face of global recessionary pressures suggesting that CSR programmes would be the first thing to be axed". Valackienè and Micevičienè (2012) note that so far the attitude to CSR and its management practices management still vary so much. The same to be said about the practices in wide range of areas, including CSR reporting and self-presentation. In fact, the former chapters of the article introduced the main pillars of sustainable development. It was also stressed that sustainable development gave birth to CSR pursuit. Valackienè et al. (2012), Valackienè and Micevičienè (2011) wrote that later on a four-part conceptualization of CSR included the idea that the corporation has not only economic, but also legal obligations as well as ethical and discretionary (philanthropic) responsibilities. The authors basing on Carroll (1991) tend to add legal pillar of CSR is to be conducted through performance in a manner consistent with expectations of government and law, successful fulfilment of enterprises legal obligation, provision of goods and services that at least meet minimal legal re- 
quirements. The ethical pillar involves the actions towards performance in a manner consistent with expectations of ethical norms and the philanthropic one is demonstrated participation of managers and employees in voluntary and charitable activities within their local communities and projects, involving enhance of communities "quality of life". But "CSR is of an enterprise is issue-specific: while demonstrating exemplary behaviour with respect to one stakeholder issue, it may fail to properly address another stakeholder interests. The degree of commitment to CSR is best evaluated at the level of an individual enterprise: within large ones various business units may face different stakeholders and their issues" (Maignan et al. 2005). "The prevailing view among most economists and business scholars is that enterprises have a compulsory duty to maximize profits for stakeholders" (Reinhardt et al. 2010). Entrepreneurship by its nature and definition driven by self-interested profit seeking motives. Naturally, senior management and many marketers still struggle to face practical implementation of CSR principles as well as they are unsure or simply have problems linking daily business activities with the well-being of society as a whole (Maignan et al. 2005). According to Branco and Rodriguese (2006), Cruz and Wakolbinger (2008), Scholtens (2008), the contribution to sustainable business may have to financial performance unfortunately relay more to quantities rather to qualities impacts.

Despite all the above mentioned aspects or motives of CSR pursuit, "indeed key players in the financial and consumer markets are asking corporations to demonstrate their ability to improve corporate process and day-by-day operations both socially and environmentally" (Perrini 2005: 611). The clarification of their identification process is presented in the following section.

\section{Promotion of CSR: integrating public expectations and enterprise value-based change}

Formally enterprise is understood as a formal organization, which operates through earned income. According to Parrish (2007) sustainable enterprise explores and examines the ends of existation and seeks to determine what it means to be the sustainable. Developing the discussion under the goals of current paper objectives we fixed shortcomings of former research. Basing on extensive review of the literature (Valackiene et al. 2012) we have come to the conclusion that most frameworks regarding the topic of an enterprise's motivation to sustain are still under development. Whilst many of the definitions available characterise the notion of CSR, businesses face the difficulty to translate the ideas and principles into action (Fairbrass et al. 2005). Especially it must be said regarding the mechanism recognition and weighting of the costs and benefits and development of further changes within an enterprise in pursuit of CSR activities according the principles of the designing of sustainable enterprise. On the basis of above statements, the authors of the paper make the following assumptions regarding the diagnostics or lightening the motives through which entrepreneurs can be motivated to contribute to sustainable development:

- an enterprise is considered to be acknowledged and the management is familiar with the framework of CSR conduct;

- an enterprise contemplays the ability to perform as sustainable one on voluntary basis; 
- the process of checking the motives as a process remains transparent, where an enterprise has access to information and data;

- the process is not static, but rather continuous;

- enterprises have the expertise and perform the analysis themselves.

To promote the idea we prepared the methodological framework (Fig. 1) to illustrate how an enterprise might fix and interpret motivations derived from external and internal

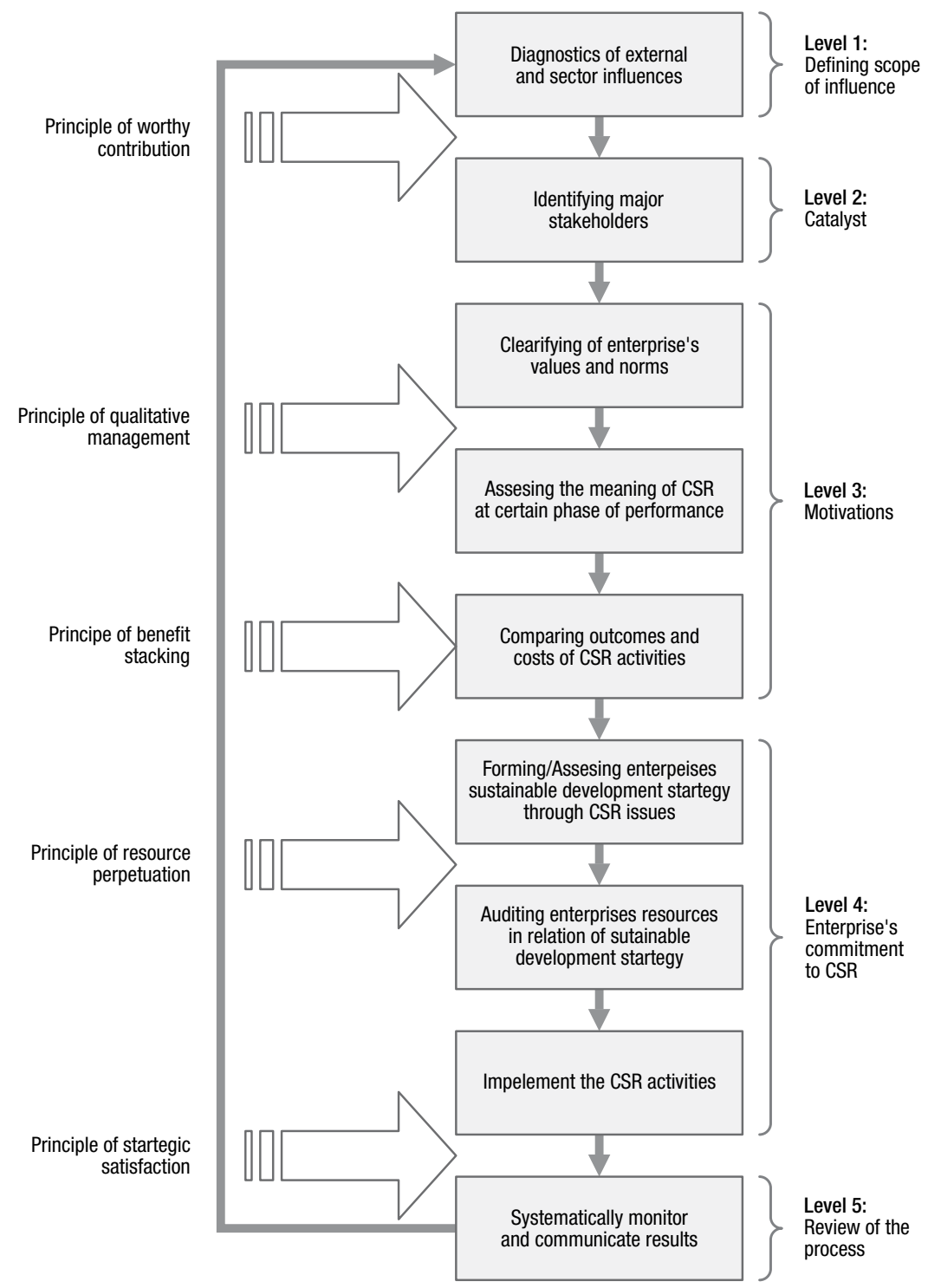

Fig. 1. Framework of diagnosing enterprise's commitment to corporate social responsibility seeking to sustain

Source: Valackienè et al. (2012: 69). 
influences as far as make decisions to act on sustainable basis through its commitment towards CSR issues and meeting the requirement of becoming sustainable (Valackiene et al. 2012).

The components of the framework provide systematic approach to analysing motivations of an enterprise to commit sustainable development issues.

Level 1: Diagnostics of external and sector influences in CSR promotion.

At this stage it is necessary to determine, the abilities of an enterprise to perform on sustainable basis, the interaction between the former and other components of the socioeconomic system is crucial. The authors of the article analysing firm's external and sector influences CSR promotion base on Parrish (2007) arguing that an open system enterprise seeks resources from its environment to ensure its own survival and runs the risk of destabilizing the larger systems of which it is a part. Enterprises are influenced by variety of factors such as available technology, political leaderships, the state of the economy, industry standards and arguments and etc. These influences might be described more in detail in terms of the influence of the following systems (Lynes, Andrachuk 2008).

Level 2: Catalyst.

"It makes sense, that the denominated catalysts" help shape influences by acting as a medium for encouraging/discouraging CSR. Culture ,shapes individual values and serves as a broad context in guiding the actions of individual and corporate actors, endorsing specific ideologies governing the relationships between firms and their natural environment, and shaping social expectations regarding the adequacy of corporate acts. While these studies acknowledge the importance of culture in enhancing the commitment of corporations to CSR, the importance in a firm's interpretation of these influences is underexplored on a case-by-case basis (Lynes, Andrachuk 2008: 380). The importance of cultural dimension at enterprise activities emphasized by other authors as well. Internal leadership, as the authors note, is the degree to which a firm takes on corporate responsibility, despite the fact so called "social champions" do not appear so prominently in the empirical evidence. Financial position is commented too briefly, but the context of the research allows concluding that financial motivations remain as achievable efficiencies in the short to medium. However, it must be stressed here that so called CSR objectives are "not stand-alone objectives, but they are integrated with all the objectives of the company and contribute ultimately to achieving the financial goals of the business" (De Palma, Dobes 2010: 1812). "What stakeholder groups they regard as important and how they perceive the interests of their stakeholders" (Steurer, Konrad 2009: 24). Companies often have mission and goals that are consistent with these principles (Veleva, Ellenbecker 2001). Taking into account that customers represent only one wide group of the stakeholder, at this stage of becoming sustainable enterprise must examine the pressure of the major stakeholder, which mostly influence its performance. 
Level 3: Motivations.

Valackienè et al. (2012) note, that recognition of individual/ mutual benefits from the process is crucial for the enterprise, seeking to become the sustainable one. Using such indicators is a continuous evolutionary proves of business transformation through awareness raising and improving dialog with stakeholders. Perrini (2005) takes into account that the initial action of an enterprise to sustain is generate of more knowledge what stakeholders need in order to serve their needs. "Corporate responsible strategic orientations seem to converge on a pool of socially responsible issues wider than in the past. These can be traced back to seven main themes: operational efficiency or group profitability, maximum safety at each level (from product and service safety to working conditions, without excluding suppliers' relationship and impact), product quality and innovation, environmental protection and contribution to widespread environmental training, dialog with stakeholders, attention to skill development (apart from its being company-oriented or community-oriented) and, finally, responsible citizenship" (Perrini 2005: 622). Enterprises being well informed must not only detects their values meet the interests of stakeholders but measure private costs of clearly determined CSR implications as well as experiencing in evaluating its social benefits, leading to achieve the goals. The reality, that investors have an expectation of a return (Sekerka, Stimel 2011). This stage meets the principles of benefit stacking and qualitative management in former analysis of the paper.

Level 4: Enterprises commitment to CSR.

"To establish sustainable enterprise leaders can not simply impose changes to the existing structure, rather deeper level of understanding is co created by people representing all areas of the system. Transformation can evoke innovation, helping employees imagine future and the enterprises role in that ideal. Processes to cultivate this type of change move people to identify strengths to conduct operations. In the case the changes are important for surface strategies, to alter the culture of organizations towards sustainable enterprise" (Sekerka, Simel 2011: 7). The authors emphasize the importance of the strategic planning in the achievement of the sustainable development issues in the level of an enterprise. The sustainable enterprise can be defined as an enterprise, "which is able to sustain and/or enhance its value at all levels of the management pyramid, consistent with each other and with the carrying capacity of the environment and with the concerns of its stakeholders" (De Palma, Dobes 2010: 1812). Lithuanian scientists also proposed to be employed to set up long-term goals and choose the main directions of business strategy of an enterprise, to distribute financial, human and other resources for strategic actions to be designed and implemented. De Palma and Dobes (2010: 1808) analyzing the performance objectives of enterprises pertaining to social dimensions, emphasized the close connection between functional strategies, their key elements and performance objectives:

- marketing strategy;

- operational strategy;

- financial strategy. 
Valackienè et al. (2012) basing on Van Marrewijk (2002) suggests differentiate strategic commitment to CSR through several ambition levels - spiral dynamics. The first step in it - compliance driven, consisting of providing welfare to society within limits to regulations from the rightful authorities. The motives for CSR - duty, obligation behaviour. The next step in the spiral - profit driven CSR. Caring CSR - the next step consisting of balanced economic, social, ecological concerns within the initiatives going beyond profit considerations and motivating to take care of the planet. This stage meets the principle of resource perpetuation and strategic satisfactions.

Level 5: Review of the process.

With respect to CSR activity and performance monitoring is one of the most important issues seeking to sustain. By embedding CSR further into its overall risk management, control and measuring systems, an enterprise might tend to better manage its socially responsible business practices and make its CSR performance more transparent and mutually beneficial to the organization and to all its stakeholders.

\section{Conclusions and discussions}

Discussing on the scientific value of the current research, it must be concluded that the authors demonstrated the main insights in developing the methodology of diagnosing the motives through which entrepreneurs can be encouraged to contribute to sustainable development by making beneficial in wide range of aspect the main strengths of which are: structures guidance of the decision making, which promotes the manifestation of several standards step at the same time leaving space for individual modification of actions within the scope of each steps. It also stress continuous improvement of decision making in meeting the sustainable development issues, encourages active involvement on management and front line workers in the process evaluation and its improvement.

At the same time we must point the limitations of the former methodology, concluding that at this step the framework of the model demonstrates the process under which enterprises demonstrates clear commitment towards CRS promotion. The second issue here is that at present conditions, expanded databases, active collaboration with the governmental institutions as well as appropriate and unlimited information flows is needed. The distinctive and more detailed criteria and set of indicators of data analysis and decision making are necessary for and might be conducted as guidelines of further research of the authors especially those providing information on cost-benefit investigation. Further analysis is need to decide what are the main barriers to implement the methodology in practice as well as detection what boundaries might influence the process of evaluation.

Summarizing the scientific literature the conclusion was drawn sustainable development has emerged as an increasingly influential concept in managerial and academic spheres and becomes a mainstay of strategies of many enterprise strategies. Going through the literature review, the concept of sustainable development was as focused on the need to integrate the pursuit of improved human well-being with the necessity of halting and recessing ecological degradation. The essence of this form of development is a stable 
relationship between human activities and the natural world, which does not diminish the prospects for future generations to enjoy a quality of life and provides visions that eclipses modernity's concept of progress by redefining the intellectual and ethic challenges so widely integrated into the analysis of CRS.

Presenting some historical facts relating to CRS development, testimony that CRS refers to the continuing commitment by business to behave ethically and contribute to economic development while improving the quality of life of the workforce and their families as well as of the local community and society at large: acting responsibly in its relationships with other stakeholders who have a legitimate interest in the activities of enterprises. Throughout analysis of CRS pillars allow to state, that enterprise conducts to CRS reporting social, economic, environmental, legal and philanthropic responsibilities and performing on sustainable basis - this was the crucial question of further investigation of the authors of the paper. The reason for that was the finding based on literature review as far as overview of present state of CRS in the Baltic states that commitment to CRS at enterprise level requires adopt values and norms along with organizational processes to minimize their negative impacts and maximize their positive impacts on important stakeholder issues. Therefore, while demonstrating exemplary behaviour with respect to one stakeholder issue, it may fail to properly address other stakeholder interests inside as well as outside the enterprise firstly in terms of profit scarifying. Summarizing it might be concluded that distinguishing between motivations of CRS and its outcomes is even more difficult and complex, then identification of the nature and content of CRS activities in the level of an enterprise. For the reason the motives of performing according principles of sustainable enterprise through demonstration of adequate CRS commitment are discussed in detail stating that the academic literature is scare in practical suggestions for enterprises seeking to sustain. Seeking to overcome the challenge, we do preset the methodological framework or better to say insights of diagnosing enterprise's commitment to corporate social responsibility seeking to sustain, covering five stages:

Level 1: Diagnostics of external and sector influences (including the analysis of scientific, political and social environment).

Level 2: Catalyst (helping to determine the core stakeholders, whose interests must be treated seriously).

Level 3: Motivations (weighting the benefits and cots in CRS commitment at the level of an enterprise and selecting proper action directions).

Level 4: Enterprises commitment to CRS (evaluating of entrepreneurial dynamic resource needs).

Level 5: Review of the process (systematic monitoring the process towards better conduct). 


\section{References}

Banerjee, S. B. 2008. Corporate social responsibility: the good, the bad and the ugly, Critical Sociology 34(1): 51-79.

Bourdages, J. L. 1997. Sustainable development: conditions, principles and issues. Backgroung paper [online], [cited 5 March 2012 ]. Parliamentary research branch. Libriary of parlament. Canada. Available from Internet: http://www.parl.gc.ca/Content/LOP/ResearchPublications/bp458-e.pdf Branco, M. C.; Rodrigues, L. L. 2006. Corporate social responsibility and resource based perspectives, Journal of Business Ethics 69: 111-132.

Carrol, A. B. 1991. The pyramid of corporate social resonsibility: toward the moral management of organizational stakeholders, Business Horizons 34(4): 39-48.

http://dx.doi.org/10.1016/0007-6813(91)90005-G

Cohen, B.; Winn, M. I. 2007. Market imperfections, opportunity and sustainable entrepreneurship, Journal of Business Venturing 22(1): 29-49. http://dx.doi.org/10.1016/j.jbusvent.2004.12.001

Commission on Environment and Development. 1987. Our common future. Report. Official Records of the General Assembly, Forty-second Session, Supplement 25 (A/42/25).

Cruz, J. M.; Wakolbinger, T. 2008. Multiperiod effects of corporate social responsibility on supply chain networks, transaction costs, emissions, and risk, International Journal of Production Economics 116(1): 61-74. http://dx.doi.org/10.1016/j.ijpe.2008.07.011

De Palma, R.; Dobes, V. 2010. An integrated approach towards sustainable entrepreneurship - experience from the TEST project in transitional economies, Journal of Cleaner Production 1(18): 1807-1821. http://dx.doi.org/10.1016/j.jclepro.2010.07.025

Fairbrass, J.; O’Riordan, L.; Mirza, H. 2005. Corporate social responsibility: differing definitions and practices?, Paper prepared for the Bussiness Strategy and the Environment Conference "Incorporateing the Corporate Social Responsibility \&Environmental Management Conference", 5-6 September 2005, University od Leeds, Yorshire, Uk.

Font, X; Harris, C. 2004. Rethinking standards from green to sustainable, Annals of Tourism Research 31(4): 986-1007. http://dx.doi.org/10.1016/j.annals.2004.04.001

Gladwin, T. N.; Kennelly, J. J.; Krause, T. S. 1995. Shifting paradigms for sustainable development: implications for management theory and research, Academy of Management Review 20: 874-907 [online]. Available from Internet: http://www.jstor.org

Hall, J.; Daneke, G.; Lenox, M. 2010. Sustainable development and entrepreneurship: past contributions and future directions, Journal of Business Venturing 25(5): 439-448.

Harwood, I. A.; Humby, S.; Harwood, A. 2011. On the resilience of corporate social responsibility, European Management Journal 29(4): 283-290. http://dx.doi.org/10.1016/j.emj.2011.04.001

Hediger, W. 2010. Welfare and capital - theoretic foundations of corporate social responsibility and corporate sustainability, Journal of Socio-Economics 39: 518-526.

http://dx.doi.org/10.1016/j.socec.2010.02.001

Lynes, J. K.; Andrachuk, M. 2008. Motivations for corporate social and environmental responsibility: a case study of Scandinavian Airlines, Journal of International Management 14(4): 377-390. http://dx.doi.org/10.1016/j.intman.2007.09.004

Maignan, I.; Ferrel, O. C.; Ferrel, L. 2005. A stakeholder model for implementing social responsibility in marketing, European Journal of Marketing 39(9/10): 956-977.

http://dx.doi.org/10.1108/03090560510610662

Markley, M. J.; Davis, L. 2007. Exploring future competitive advantage through sustainable supply chains, International Journal of Physical Distribution \& Logistics Management 37(9): 763-774. http://dx.doi.org/10.5465/AMR.2005.15281448 
Parrish, B. D. 2009. Sustainability-driven entrepreneurship: principles of organization design, Journal of Business Venturing 25(5): 510-523.

http://dx.doi.org/10.1016/j.jbusvent.2009.05.005

Parrish, B. D. 2007. Designing the sustainable enterprise, Futures 39: 846-860.

http://dx.doi.org/10.1016/j.futures.2006.12.007

Perrini, F. 2005. Building a European portrait of corporate social responsibility reporting, European Management Journal 23(6): 611-627. http://dx.doi.org/10.1016/j.emj.2005.10.008

Reinhardt, F. L.; Stavins, R. N.; Vietor, H. K. 2010. Corporate social responsibility through economic lens, Review of Environmental Economics and Policy 2(2): 219-239.

http://dx.doi.org/10.1093/reep/ren008

Scholtens, B. 2008. A note on the interaction between corporate social responsibility and financial performance, Ecological Economics 68(1-2): 46-55.

http://dx.doi.org/10.1016/j.ecolecon.2008.01.024

Sekerka, L. E.; Stimel, D. 2011. How durable is sustainable enterprise? Ecological sustainability meets the reality of tough economic times, Business Horizons 54(2): 115-124.

http://dx.doi.org/10.1016/j.bushor.2010.09.006

Spector, B. 2008. Business responsibilities in a divided world: the Cold War roots of the corporate social responsibility movement, Enterprise \& Society 9(2): 314-336.

http://dx.doi.org/10.1093/es/khn023

Steurer, R.; Konrad, A. 2009. Business-society relations in Central-Eastern and Western Europe: how those who lead in sustainability reporting bridge the gap in corporate (social) responsibility, Scandinavian Journal of Management 25(1): 23-36.

http://dx.doi.org/10.1016/j.scaman.2008.11.001

Torjman, S. 2000. The social dimension of sustainable development. Calendon Institute of Social Policy. 11 p. ISBN 1-894598-00-8.

Valackienè, A.; Micevičienè, D. 2012. Benchmarking of corporate social responsibility: from the perspective of stakeholders to the interests of an enterprise, Transformations in Business \& Economics 11(2): 202-217.

Valackienè, A.; Micevičienè, D. 2011. Methodological framework analysing a social phenomenon: stakeholder orientation implementing balanced corporate social responsibility, Inzinerine ekonomika - Engineering Economics 22(3): 300-308.

Valackienè, A.; Susnienè, D.; Micevičienè, D. 2012. Corporate social responsibility initiatives integrating stakeholder approach: implications for Lithuania. Research study. Kaunas: Technologija. 179 p. ISBN 9786090204115.

Van Marrewijk, M. 2002. Concepts and definitions of CSR and corporate sustainability - between agency and communion [online], [cited 5 March 2011]. Available from Internet: http://ecsf.info/ uploaded/040526131225.pdf

Veleva, V.; Ellenbecker, M. 2001. Indicatots of sutainable production: framework and methodology, Journal of Cleaner Production 9: 519-549.

Werther, B. W.; Chandler, D. 2005. Strategic corporate social repsonsibility as global brand insurance, Business Horizons 48(4): 317-324. 
Asta VALACKIENĖ. Professor, Doctor of Social Sciences (Sociology, Management and Administration), dean of Faculty of Management and Administration, Kaunas University of Technology Panevežys Institute. Asta Valackiene gives lectures for businessmen and state officials on crisis management and decision making. The author published 6 articles in referred Social Sciences Citation Index (Web of Science) and 40 articles on other reviewed scientific journals, and is the author of some textbooks, course books and methodological books.

Diana MICEVIČIENĖ. Associate Professor, Doctor of Social Sciences (Economics), Kaunas University of Technology Panevežys Institute, Faculty of Management and Administration. The author published 9 articles in referred publications (ISI proceedings), other in reviewed scientific journals from the list of international databases. 